\title{
TRANSFORMASI SOSIO - SPASIAL BERBASIS PARIWISATA DI DESA TEMUKUS
}

\author{
Nyoman Tri Wahyuningsih, I Putu Ananda Citra, Putu Indra Christiawan \\ Jurusan Pendidikan Geografi \\ Universitas Pendidikan Ganesha \\ Singaraja, Indonesia
}

Email: Nyomantriwahyningsih@gmail.com, ananda.citra@undiksha.ac.id, putu.ic87@gmail.com,

\begin{abstract}
Abstrak
Penelitian dilaksanakan di Desa Temukus, yang bertujuan untuk: (1) Menganalisis transformasi fisik berbasis pariwisata, (2) Menganalisis transformasi sosial ekonomi berbasis pariwisata. Penelitian ini menggunakan penelitian kualitatif. Sampel berjumlah $53 \mathrm{KK}$ yang ditentukan secara purposive sampling Pengumpulan data menggunakan teknik observasi, wawancara, dan dokumentasi. Data dianalisis dengan teknik kualitatif. Hasil penelitian ini menunjukkan bahwa: (1) terjadi transformasi fisik berupa akomodasi pariwisata di Desa Temukus dari tahun 2012 dan 2016, yakni sebesar 105\% yang berkategori tinggi, dan transformasi infrastruktur berupa perubahan panjang jalan sebesar $204 \%$ yang berkategori tinggi. Tingginya transformasi fisik ini dikarenakan, semakin bertambahnya investor atau pihak swasta yang ingin membangun akomodasi pariwisata, serta banyaknya masyarakat yang menjual lahan khususnya lahan pertanian yang akan digunakan untuk pembangunan akomodasi pariwisata di Desa Temukus. (2) terjadi transformasi sosial ekonomi yaitu perubahan mata pencaharaian serta pendapatan di Desa Temukus. Transformasi mata pencaharian di Desa Temukus dari tahun 2012 dan 2016 adalah sebesar $85.21 \%$ yang berkategori tinggi, sedangkan transformasi pendapatan dari tahun 2012 dan 2016 sebesar $22.24 \%$ yang berkategori rendah. Transformasi mata pencaharian yang berkategori tinggi dikarenakan semakin banyaknya masyarakat Desa Temukus yang berkecimpung dalam industri pariwisata, selain itu ada beberapa alasan lain seperti keinginan untuk merubah nasib kearah yang lebih baik serta adanya keinginan untuk mencari pengalaman baru di industri pariwisata.
\end{abstract}

“kata kunci”: Pariwisata, Transformasi Fisik, Transformasi Sosial-Ekonomi.

\begin{abstract}
The research was conducted in Temukus Village, which aims to: (1) analyze the physical transformation based on tourism, (2) analyze the socio-economic transformation based on tourism. This research uses qualitative research. The number of subject sample to 53 house hold. Which determined by purposive sampling. Data collecting using observation technique, interview, and documentation The data are analyzed by qualitative technique. The result of research indicate that: (1) there is a physical transformation of tourism accomodation in Temukus village from 2012 and 2016 that aqual to $105 \%$ which is categorized high, and infrastructure transformation in the long road change of $204 \%$ which are categorized as high. The high physical transformation is due to the increasing number of investors or private parties who want to build tourism accommodation, as well as the many people who sell land, especially agricultural land that will be used for the construction of tourism accommodation in Temukus Village. (2) There is a socio-conomic transformation of livelihoods change in Temukus Village from 2012 and 2016 a mounted to $85.21 \%$ which is categorized high, while revenue transformation from 2012 and 2016 is $22.24 \%$ which categorized as low. The transformation Livelihoods that categorized high due to the increasing number of Temukus village who are involved in tourism industry, in addition there are several other reasons such as the desire to change the fate. Towards the better and the desire to seek new experiences in the tourism industry.
\end{abstract}

"Keywords": Tourism, Physical Transformation, Socio-Economic Transformation. 


\section{PENDAHULUAN}

Pertemuan Nasional Pariwisata mendefinisikan pariwisata sebagai suatu penyelenggaraan kegiatan wisata yang bertanggung jawab pada daerah alami atau daerah yang dibuat berdasarkan kaidah alam yang mendukung upaya pelestarian lingkungan dan meningkatkan kesejahteraan masyarakat setempat (Kusudianto, 1996).

Tujuan pariwisata adalah memberikan keuntungan baik warga setempat maupun bagi wisatawan. Bagi Masyarakat pariwisata mampu memberikan kehidupan melalui keuntungan ekonomi yang didapat dari tempat tujuan wisata (Happy, 2002).

Terdapat tiga faktor yang dapat menentukan keberhasilan perkembangan pariwisata sebagai suatu industri, yaitu: 1) Tersedianya obyek atraksi wisata, 2) Adanya fasilitas dan aksesibilitas yang baik, 3) Bernilai untuk dikunjungi dan dilihat. Disisi lain perkembangan pariwisata semakin berhasil ketika tersedia fasilitas pendukung seperti tempat penginapan, hiburan, restoran, dan transportasi lokal yang memudahkan aksesibilitas wisatawan (Yoeti, 1999).

Banyak keuntungan yang diperoleh dengan berkembanganya kepariwisataan, antara lain ialah meningkatnya pendapatan daerah, terdapatnya peluang kerja atau usaha baru, peningkatan devisa negara, dan lain sebagainya. Banyaknya wisatawan baik domestik maupun mancanegara yang semakin meningkat, cenderung dapat memberikan kontribusi terhadap peingkatkan pendapatan penduduk daerah tujuan wisata.

Seiring adanya peningkatan pendapatan, maka kualiatas hidup masyarakat juga akan semakin meningkat. Hal ini dicirikan dengan adanya pola konsumtif serta gaya hidup yang semakin meningkat pula. Berkembangnya suatu daerah menjadi daerah tujuan wisata, memberikan kontribusi positif selain itu juga selalu disertai dengan kontribusi yang negatif salah satunya, menimbulkan perubahan-perubahan fisik dan sosial dikalangan masyarakat setempat. Perkembangan pariwisata di Kabupaten Buleleng kini mengalami peningkatan yang signifikan. Hal ini dibuktikan dengan jumlah kunjungan wisatwan ke objek wisata yang terdapat di Kabupaten Buleleng yang mengalami peningkatan di setiap tahunnya baik dari wisatawan domestik maupun wisatawan mancanegara. perkembangan pariwisata akan memberikan kontribusi tidak hanya dari sisi ekonomi, akan tetapi juga berkontribusi terhadap perubahan fisik dan sosial masyarakat. Begitu pula yang terjadi di Desa Temukus, dari sisi ekonomi perkembangan pariwisata memberikan keuntungan bagi perekonomian desa. Disisi lainnya perkembangan pariwisata pada akhirnya mengorbankan lahan pertanian karena maraknya pembangunan fasilitas dan infrastruktur, hotel, vila, home stay serta restaurant demi menunjang pariwisata yang terdapat $\mathrm{Di}$ Desa Temukus. Seiring perkembangan pariwisata di Desa Temukus lahan pertanian mengalami penyusutan.

Banyaknya kunjungan wisatawan secara tidak langsung menuntut adanya pemenuhan sarana dan prasarana yang mampu mendukung terselenggaranya kegiatan pariwisata, dan tentunya akan cenderung berpengaruh terhadap kondisi fisik Desa Temukus baik dilihat dari segi akomodasi dan infrastruktur pariwisata. Selain itu juga akan berkontribusi terhadap kondisi sosial masyarakat Desa Temukus, dari adanya perkembangan pariwisata ini akan menuntut adanya perubahan mata pencaharian masyarakat setempat.

Atmaja (2015) menyatakan bahwa Meningkatnya permintaan lahan telah mengakibatkan pemilikan lahan sawah petani semakin sempit, namun karena lahan sawah masih merupakan sumber mata pencaharian pokok sebagian besar petani, maka beberapa petani selalu berusaha memanfaatkan secara intensif dengan berbagai komoditi pertanian untuk meningkatkan pendapatannya, namun selain merubah komoditi pertanian beberapa petani cendrung merubah mata pencaharaian di sektor pariwisata demi meningkatkan pendapatannya.

Pada mulanya masyarakat bermata pencaharian petani akan berangsur-angsur berubah menjadi pelaku usaha wisata, dari adanya perubahan mata pencaharian ini cenderung akan berkontribusi terhadap menurunya produksi pangan karena berkurangnya pekerja dalam menggarap lahan pertanian yang disebabkan dari 
adanya perkembangan pariwisata di Desa Temukus. Permasalahan pada penelitian ini (1) Bagaimana transformasi fisik berbasis pariwisata Di Desa Temukus, (2) Bagaimana transformasi sosial ekonomi berbasis pariwisata Di Desa Temukus. Tujuan pada penelitian ini yaitu (1) Menganalisis transformasi fisik berbasis pariwisata Di Desa Temukus, (2) Menganalisis transformasi sosial ekonomi berbasis pariwisata Di Desa Temukus.

\section{METODE}

Penelitian ini dilakukan di Desa Temukus. Objek dalam penelitian ini adalah transformasi sosio-spasial berbasis pariwisata. Subjek dalam penelitian ini adalah masyarakat yang terkait dengan transformasi sosio-spasial berbasis pariwisata di Desa Temukus. Populasi dari penelitian ini adalah masyarakat yang terkait dengan tranformasi sosio-spasial berbasis pariwisata di Desa Temukus terdiri dari para tokoh masnyarakat, pemerintah serta masyarakat Desa Temukus, sampel dalam penelitian ini sejumlah $53 \mathrm{KK}$ yang ditentukan secara purposive sampling. Teknik pengumpulan data yaitu observasi lapangan, wawancara dan dokumentasi. Data primer yang telah dikumpulkan selanjutnya akan dianalisis menggunakan analisis Kualitatif. Terkait dengan kondisi fisik menggunakan pendekatan keruangan dengan tema analisis pola keruangan. Terkait dengan kondisi sosial ekonomi pendekatan keruangan dengan tema analisis struktur keruangan.

\section{HASIL}

\section{Transformasi Fisik Berbasis Pariwisata Di Desa Temukus}

\section{Akomodasi dan Infrastruktur Pariwisata}

Perkembangan pariwisata di Desa Temukus tentunya akan memberikan kontribusi terhadap transformasi fisik seperti adanya pembangunan akomodasi dan infrastruktur pariwisata. Sama halnya dalam penelitian Fitri (2014) yang berjudul "ECOResort dan Green Hotel di Indonesia : Model Sarana Akomodasi yang Berkelanjutan" menyatakan bahwa Perkembangan kepariwisataan yang ditandai dengan jumlah wisatawan Nasional dan mancanegara yang terus meningkat memberikan implikasi terhadap peningkatan pertumbuhan sarana prasarana pariwisata. Jumlah wisatawan nasional pada tahun 2012 mencapai 7.310.531 wisatawan dengan tingkat pertumbuhan sebesar $7,3 \%$ mendorong peningkatan pertumbuhan sarana pariwisata berupa hotel bintang maupun non bintang sebesar $12 \%$ di tahun 2012 .

Pembangunan akomodasi dan infrastruktur ini tentunya akan memberikan kontribusi terhadap penyusutan luas lahan pertanian. Penelitian dari Rossi (2012) yang berjudul "Dampak Perkembangan Pembangunan Sarana Akomodasi Wisata Terhadap Pariwisata Berkelanjutan Di Bali" menunjukkan bahwa adanya pembangunan villa dan fasilitas wisata lainnya, mengakibatkan banyaknya lahan produktif untuk pertanian telah diubah menjadi tempattempat akomodasi wisata. Sehingga dari tahun ke tahun lahan produktif pertanian semakin menyusut serta hasil produksi pertanian mengalami penurunan, Selain itu, berkontribusi pula terhadap pembangunan terhadap lingkungan sekitarnya, seperti aliran air untuk pertanian karena dialihkan untuk kebutuhan konstruksi.

Sejalan dengan penelitian tersebut perkembangan pariwisata di Desa Temukus juga memberikan kotntribusi terhadap penyusutan luas lahan khususnya pada luas lahan pertanian yang ada di Desa Temukus, dimana dalam kurun waktu lima tahun terakhir telah terjadi penyutusutan luas lahan pertanian dikarenakan adanya alih fungsi lahan menjadi non pertanianan disajikan pada Tabel Luas Penggunaan Lahan Desa Temukus Tahun 2012 berikut. 
Tabel 1. Luas Penggunaan Lahan Desa Temukus Tahun 2012

\begin{tabular}{llcc}
\hline No & $\begin{array}{l}\text { Penggunaan } \\
\text { Lahan }\end{array}$ & $\begin{array}{c}\text { Luas } \\
\text { (are) }\end{array}$ & $\begin{array}{c}\text { Persentase } \\
(\%)\end{array}$ \\
\hline 1. & Semak Belukar & 2702 & 6,69 \\
2. & Sawah & 16541 & 41,01 \\
3. & Tegalan & 14528 & 36,03 \\
4. & Permukiman & 6564 & 16,27 \\
\hline Total & & $\mathbf{4 0 3 3 5}$ & $\mathbf{1 0 0}$ \\
\hline
\end{tabular}

Sumber: Pengolahan Data Skunder (citra landsat), 2017

Berdasarkan Tabel Luas Penggunaan Lahan Desa Temukus Tahun 2012, penggunaan lahan yang masih cukup luas yakni penggunaan lahan sawah dengan luas
16541 are $(41,01 \%)$ luas semak belukar adalah seluas 2702 are $(6,69 \%)$, luas tegalan 14528 are $(36,03 \%)$, luas permukiman 6564 are $(16,27 \%)$.

Tabel 2. Luas Penggunaan Lahan Desa Temukus Tahun 2016

\begin{tabular}{llcc} 
No & $\begin{array}{l}\text { Penggunaan } \\
\text { Lahan }\end{array}$ & $\begin{array}{c}\text { Luas } \\
\text { (are) }\end{array}$ & $\begin{array}{c}\text { Persentase } \\
\text { (\%) }\end{array}$ \\
\hline 1. & Semak Belukar & 2702 & 6,69 \\
2. & Sawah & 13999 & 34,72 \\
3. & Tegalan & 14268 & 35,37 \\
4. & Permukiman & 9366 & 23,22 \\
\hline Total & & $\mathbf{4 0 3 3 5}$ & $\mathbf{1 0 0}$ \\
\hline
\end{tabular}

Sumber: Pengolahan Data Skunder (citra landsat), 2017

Berdasarkan Tabel Luas Penggunaan Lahan Desa Temukus Tahun 2016 luas penggunan lahan Desa Temukus, luas semak belukar 2702 are (6,69\%), luas sawah 13999 are $(34,72 \%)$, luas tegalan 14268 are $(35,37 \%)$, luas permukiman 9366 are $(23,22 \%)$. Berdasarkan luas penggunaan lahan tahun 2012 dan 2016. Luas penggunaan lahan sawah, tegalan maupun permukiman terjadi transformasi luas penggunaan lahan yang diakibatkan dari adanya perkembangan pariwisata. Dapat dilihat pada tabel perubahan penggunaan lahan Desa Temukus Tahun 2012 dan 2016.

Tabel 3. Perubahan Penggunaan Lahan Desa Temukus Tahun 2012 dan 2016

\begin{tabular}{|c|c|c|c|c|c|c|}
\hline \multirow{2}{*}{ No } & \multirow{2}{*}{$\begin{array}{c}\text { Penggunaan } \\
\text { Lahan }\end{array}$} & \multicolumn{2}{|c|}{ Luas (are) } & \multirow{2}{*}{$\begin{array}{l}\text { Luas } \\
\text { Perubahan } \\
\text { (are) }\end{array}$} & \multirow{2}{*}{$\begin{array}{c}\text { Persentase } \\
(\%)\end{array}$} & \multirow{2}{*}{ Ket } \\
\hline & & 2012 & 2016 & & & \\
\hline 1. & Sawah & 16541 & 13999 & 2542 & 6,30 & Berkurang \\
\hline 2. & Tegalan & 14528 & 14268 & 260 & 0,64 & Berkurang \\
\hline 3. & Permukiman & 6564 & 9366 & 2802 & 6,95 & Bertambah \\
\hline Total & & 37633 & 37633 & 5604 & 13,89 & \\
\hline
\end{tabular}

Sumber: Pengolahan Data Skunder (citra landsat), 2017

Berdasarkan Tabel perubahan penggunaan lahan Desa Temukus tahun 2012 dan 2016, luas sawah berkurang menjadi 2542 are dengan persentase sebesar 6,30\% berkurang menjadi permukiman, luas tegalan berkurang menjadi 260 are dengan persentase sebesar $0,64 \%$ berkurang menjadi permukiman, serta luas permukiman bertambah menjadi 2802 are dengan persentase sebesar $6,95 \%$.
Pariwisata di Kabupaten Buleleng kini mengalami perkembangan yang cukup pesat ini dibuktikan dari semakin banyaknya kunjungan wisatawan di Kabupaten Buleleng salah satunya pada Desa Temukus, dari adanya kunjungan wisatawan yang cukup meningkat hal ini tentunya akan memberikan kontribusi terhadap pembangunan serta pembaharuan akomodasi dan infrastruktur pariwisata guna memberikan kenyamanan 
bagi para wisatawan baik wisatwan asing maupun lokal yang datang berkunjung.

Penelitian Riani (2012) dengan penelitian yang berjudul "Studi Persepsi Dampak Perubahan Pemanfaatan Lahan Terhadap Kunjungan Wisata Di Pulau Pramuka Kepulauan Seribu" menyatakan bahwa adanya peningkatan jumlah wisatawan yang berkunjung ke Pulau Pramuka memberikan pengaruh yang signifikan terhadap perubahan pemanfaatan lahan, dimana semakin tingginya lahan yang dimanfaatkan untuk pembangunan sarana dan prasarana wisata seperti pembangunan hotel dan villa. Sama halnya dengan penelitian tersebut pada lima tahun terakhir Akomodasi pariwisata Desa Temukus mengalami transformasi yang cukup pesat dari tahun 2012 dan 2016 dapat dilihat pada tabel berikut.

Tabel 4. Transformasi Akomodasi Pariwisata Desa Temukus Tahun 2012 dan 2016

\begin{tabular}{|c|c|c|c|c|c|c|c|}
\hline \multirow[b]{2}{*}{ No } & \multirow[b]{2}{*}{ Akomodasi } & \multicolumn{4}{|c|}{ Banjar } & \multirow[b]{2}{*}{$\begin{array}{l}\text { Rata- } \\
\text { rata (\%) }\end{array}$} & \multirow[b]{2}{*}{ Kategori } \\
\hline & & $\begin{array}{c}\text { Br. } \\
\text { Pegayaman }\end{array}$ & $\begin{array}{c}\text { Br. } \\
\text { Labuhan } \\
\text { Aji }\end{array}$ & $\begin{array}{c}\text { Br. } \\
\text { Bingin } \\
\text { Banjah }\end{array}$ & $\begin{array}{c}\text { Br. } \\
\text { Tengah }\end{array}$ & & \\
\hline 1. & Restaurant & 0 & 40 & 0 & 100 & 35 & Sedang \\
\hline 2. & $\begin{array}{l}\text { Penginapan } \\
\text { (hotel, vila, } \\
\text { home stay) }\end{array}$ & 12.5 & 0 & 14.29 & 0 & 6.69 & Rendah \\
\hline 3. & $\begin{array}{l}\text { mini market } \\
\text { (alfamart, } \\
\text { minimart, } \\
\text { toko, } \\
\text { pedagang } \\
\text { kecil) }\end{array}$ & 1500 & 4.35 & 10 & 5 & 380 & Tinggi \\
\hline $\begin{array}{l}\text { Rata - rata (\%) } \\
\text { Kategori }\end{array}$ & & $\begin{array}{c}504 \\
\text { Tinggi }\end{array}$ & $\begin{array}{c}14.78 \\
\text { Rendah }\end{array}$ & $\begin{array}{c}8.09 \\
\text { Rendah }\end{array}$ & $\begin{array}{c}35 \\
\text { sedang }\end{array}$ & $\begin{array}{c}105 \\
\text { Tinggi }\end{array}$ & \\
\hline
\end{tabular}

Sumber: Pengolahan Data Skunder, 2017

Berdasarkan Tabel Transformasi akomodasi Desa Temukus tahun 2012 dan 2016, akomodasi restaurant di Desa Temukus sebesar $35 \%$ termasuk transformasi sedang. Akomodasi penginapan sebesar $6.69 \%$ termasuk transformasi rendah, serta akomodasi mini market sebesar $380 \%$ termasuk transformasi tinggi. Sedangkan rata-rata transformasi fisik Desa
Temukus baik dari restaurant, penginapan, dan mini market sebesar 105\% termasuk transformasi tinggi. Selain berkontribusi terhadap akomodasi pariwisata, adanya perkembangan pariwisata juga berkontribusi terhadap transformasi fisik berupa insfrastruktur Desa Temukus disajikan pada tabel Transformasi Infrastruktur Desa Temukus Tahun 2012 dan 2016.

Tabel 5. Transformasi Infrastruktur Desa Temukus Tahun 2012 dan 2016.

\begin{tabular}{llcccccc} 
& & \multicolumn{4}{c}{ Banjar } & \\
\cline { 3 - 6 } No & Akomodasi & $\begin{array}{c}\text { Br. } \\
\text { Pegayaman }\end{array}$ & $\begin{array}{c}\text { Br. } \\
\text { Labuhan } \\
\text { Aji }\end{array}$ & $\begin{array}{c}\text { Br. } \\
\text { Bingin } \\
\text { Banjah }\end{array}$ & $\begin{array}{c}\text { Br. } \\
\text { Tengah }\end{array}$ & $\begin{array}{c}\text { Rata- } \\
\text { rata (\%) }\end{array}$ & Kategori \\
\hline 1. & $\begin{array}{l}\text { Panjang } \\
\text { jalan }\end{array}$ & 0 & 204 & 0 & 0 & $\mathbf{2 0 4}$ & Tinggi \\
Jembatan & 0 & 0 & 0 & 0 & $\mathbf{0}$ & Rendah \\
\hline
\end{tabular}

Sumber: Pengolahan Data Skunder, 2017

Berdasarkan Tabel Transformasi infrastruktur Desa Temukus tahun 2012 dan 2016, hanya panjang jalan Desa Temukus yang mengalami transformasi dengan persentase sebesar 204\% termasuk transformasi tinggi. Sedangkan pada infrastruktur lainnya seperti jembatan tidak mengalami transformasi dan untuk infranstruktur trotar tidak tersedia di Desa Temukus. 


\section{Transformasi Sosial Ekonomi Berbasis Pariwisata Di Desa Temukus}

\section{Mata Pencaharian dan Pendapatan}

Berkembangnya pariwisata Desa Temukus tentunya juga akan berkontribusi terhadap kondisi sosial ekonomi masyarakat Desa Temukus, Adanya perubahan mata pencaharian ini cenderung akan berkontribusi terhadap menurunya produksi pangan karena berkurangnya pekerja dalam menggarap lahan pertanian yang disebabkan dari adanya perkembangan pariwisata.

Penelitian Menuh (2016) dengan penelitian yang berjudul "Karakteristik Wisatawan Backpacker Dan Dampaknya
Terhadap Pariwisata Kuta, Bali" menyatakan bahwa pesatnya perkembangan pariwisata di Kuta memberikan dampak terhadap perubahan mata pencaharian, dimana semakin meningkatnya masyarakat yang beralih mata pencaharaian dari sektor non pariwisata ke sektor pariwisata yang berimplikasi terhadap peningkatan pendapatan masyarkat di Kuta, Bali. Sama halnya dengan penelitian tersebut perkembangan pariwisata di Desa Temukus juga berkontribusi terhadap perubahan mata pencaharian dari sektor non pariwisata ke sektor pariwisata disajikan pada tabel Transformasi Mata Pencaharian Desa Temukus Tahun 2012 dan 2016.

Tabel 6. Transformasi Mata Pencaharian Desa Temukus Tahun 2012 dan 2016.

\begin{tabular}{|c|c|c|c|c|c|c|c|}
\hline \multirow[b]{2}{*}{ No } & \multirow[b]{2}{*}{$\begin{array}{c}\text { Mata } \\
\text { Pencaharian }\end{array}$} & \multicolumn{4}{|c|}{ Banjar } & \multirow[b]{2}{*}{$\begin{array}{c}\text { Rata- } \\
\text { rata } \\
(\%)\end{array}$} & \multirow[b]{2}{*}{ Kategori } \\
\hline & & $\begin{array}{c}\text { Br. } \\
\text { Pegayaman }\end{array}$ & $\begin{array}{c}\text { Br. } \\
\text { Labuhan } \\
\text { Aji }\end{array}$ & $\begin{array}{c}\text { Br. } \\
\text { Bingin } \\
\text { Banjah }\end{array}$ & $\begin{array}{c}\text { Br. } \\
\text { Tengah }\end{array}$ & & \\
\hline 1. & $\begin{array}{l}\text { Pelaku } \\
\text { usaha wisata }\end{array}$ & 95 & 840 & 62.5 & 170 & 292 & Tinggi \\
\hline 2. & Petani & 10 & 25 & 0 & 8 & 10.75 & Rendah \\
\hline 3. & $\begin{array}{l}\text { Pemilik lahan } \\
\text { sawah }\end{array}$ & 62.5 & 40 & 0 & 50.4 & 38.23 & Sedang \\
\hline $\begin{array}{l}\text { Rata- rata (\%) } \\
\text { Kategori }\end{array}$ & & $\begin{array}{l}55.83 \\
\text { Sedang }\end{array}$ & $\begin{array}{c}301 \\
\text { Tinggi }\end{array}$ & $\begin{array}{c}20.83 \\
\text { Rendah }\end{array}$ & $\begin{array}{l}76.13 \\
\text { Tinggi }\end{array}$ & $\begin{array}{l}85.21 \\
\text { Tinggi }\end{array}$ & \\
\hline
\end{tabular}

Sumber: Pengolahan Data Skunder, 2017

Berdasarkan Tabel Transformasi mata pencaharian Desa Temukus tahun 2012 dan 2016, mata pencaharian sebagai pelaku usaha wisata sebesar $292 \%$ termasuk transformasi tinggi. Mata pencaharian sebagai petani sebesar $10.75 \%$ termasuk transformasi rendah, serta mata pencaharian sebagai pemilik lahan sawah sebesar $38.23 \%$ termasuk transformasi sedang. Sedangkan rata-rata transformasi mata pencaharian di Desa Temukus baik dari pelaku usaha wisata, petani, dan pemilik lahan adalah sebesar $85.21 \%$ dan termasuk transformasi tinggi.

Perkembangan pariwisata tentunya telah memberikan kontribusi yang baik terhadap Desa Temukus, hal ini dapat dilihat dari terjadinya transformasi mata pencaharia Desa Temukus. Adanya transformasi mata pencahariantentunya akan memberikan kontribusi pula terhadap perubahan pendapatan di daerah wisata. Penelitian Hanny (2011) dengan penelitian yang berjudul "Dampak Ekonomi Pengembangan Kawasan Ekowisata Kepulauan Seribu" menyatakan bahwa Pengembangan kawasan ekowisata di Kabupaten Kepulauan Seribu memberikan dampak yang sangat baik terhadap perekonomian masyarakat di wilayah tersebut. Ekowisata di Kabupaten Kepulauan Seribu berpengaruh yang cukup besar terhadap meningkatnya pendapatan usaha masyarakat di wilayah tersebut. Penduduk yang memiliki usaha yang berkaitan langsung dengan kegiatan pariwisata di Kabupaten Kepulauan Seribu ini mengalami peningkatan pendapatan sejak pariwisata semakin berkembang di daerah tersebut. Hal ini meliputi Akomodasi, Restauran/Makanan dan Minuman, Transportasi, dan Souvenir. Jasa-jasa dan perdagangan-perdagangan informal seperti PKL dan warung-warung.

Sejalan dengan penelitian tersebut perkembangan pariwisata di Desa Temukus juga memberikan kontribusi terhadap 
perubahan pendapatan, dimana semakin bertambahnya masyarakat yang bekerja sebagai pelaku usaha wisata dan semakin sedikitnya masyarakat yang bekerja sebagai petani serta pemilik lahan sawah, tentunya akan memberikan kontribusi terhadap pendapatan di masing-masing mata pencaharian disajikan pada tabel Transformasi Pendapatan Desa Temukus Tahun 2012 dan 2016.

Tabel 7. Transformasi Pendapatan Desa Temukus Tahun 2012 dan 2016.

\begin{tabular}{|c|c|c|c|c|c|c|c|}
\hline \multirow[b]{2}{*}{ No } & \multirow[b]{2}{*}{$\begin{array}{c}\text { Mata } \\
\text { Pencaharian }\end{array}$} & \multicolumn{4}{|c|}{ Banjar } & \multirow[b]{2}{*}{$\begin{array}{l}\text { Rata- } \\
\text { rata } \\
(\%)\end{array}$} & \multirow[b]{2}{*}{ Kategori } \\
\hline & & $\begin{array}{c}\text { Br. } \\
\text { Pegayaman }\end{array}$ & $\begin{array}{c}\text { Br. } \\
\text { Labuhan } \\
\text { Aji }\end{array}$ & $\begin{array}{c}\text { Br. } \\
\text { Bingin } \\
\text { Banjah }\end{array}$ & $\begin{array}{c}\text { Br. } \\
\text { Tengah }\end{array}$ & & \\
\hline 1. & $\begin{array}{l}\text { Pelaku } \\
\text { usaha wisata }\end{array}$ & 12.5 & 25 & 11.11 & 20 & 17.15 & Rendah \\
\hline 2. & Petani & 50 & 50 & 0 & 33.33 & 33.33 & Rendah \\
\hline 3. & $\begin{array}{l}\text { Pemilik lahan } \\
\text { sawah }\end{array}$ & 20 & 20 & 0 & 25 & 16.25 & Rendah \\
\hline $\begin{array}{l}\text { Rata-rata (\%) } \\
\text { Kategori }\end{array}$ & & $\begin{array}{c}27.5 \\
\text { Rendah }\end{array}$ & $\begin{array}{c}31.66 \\
\text { Rendah }\end{array}$ & $\begin{array}{c}3.70 \\
\text { Rendah }\end{array}$ & $\begin{array}{c}26.11 \\
\text { Rendah }\end{array}$ & $\begin{array}{c}22.24 \\
\text { Rendah }\end{array}$ & \\
\hline
\end{tabular}

Sumber: Pengolahan Data Skunder, 2017

Berdasarkan Tabel Transformasi pendapatan Desa Temukus tahun 2012 dan 2016, pendapatan pada mata pencaharian sebagai pelaku usaha wisata di Desa Temukus sebesar $17.15 \%$ termasuk transformasi rendah. Pendapatan mata pencaharian sebagai petani sebesar $33.33 \%$ termasuk transformasi sedang, serta pendapatan mata pencaharian sebagai pemilik lahan sawah sebesar $16.25 \%$ termasuk transformasi rendah. Sedangkan rata-rata transformasi pendapatan Desa Temukus baik pada pendapatan sebgai pelaku usaha wisata, petani, dan pemilik lahan adalah sebesar $22.24 \%$ termasuk transformasi rendah.

\section{PEMBAHASAN}

\section{Transformasi Fisik Berbasis Pariwisata Di Desa Temukus}

Adanya transformasi fisik berupa akomodasi pariwisata ini rata-rata terjadi apa setiap Banjar di Desa Temukus, Banjar yang mengalami transformasi akomodasi pariwisata tertinggi baik dari restaurant, penginapan (hotel, vila, home stay) dan mini market (alfamart, minimart, toko, pedagang kecil), yakni Banjar Pegayaman.

Peningkatan transformasi akomodasi pariwisata di Banjar Pegayaman terutama pada penambahan mini market dikarenakan Banjar Pegayamn merupakan banjar yang masih memiliki cukup lahan untuk pembangunan mini market, selain itu Banjar Pegayaman memiliki lokasi yang strategis dimana lokasi banjar berada tepat di sebelah barat dari objek wisata terkenal di Desa Temukus, dan lokasi Banjar Pegayaman sangat mudah untuk dijangkau sehingga membuat para investor swasta tertarik untuk membangun akomodasi pariwisata seperti mini market demi menunjang kenyamanan wisatawan yang berkunjung di Desa Temukus.

Selain terdapat Banjar yang mengalami transformasi fisik tertinggi terdapat pula Banjar yang mengalamai transformasi fisik terkecil, yakni Banjar Bingin Banjah. Hal ini dikarenakan Banjar Bingin Banjah merupakan banjar yang sudah memiliki akomodasi pariwisata yang cukup dari awal adanya pariwisata, seperti misalnya jumlah restaurant, penginapan dan mini market yang cukup dalam menunjang pariwisata di Desa Temukus, selain itu rendahnya transformasi fisik Banjar Bingin Banjah dibandingkan dengan Banjar lain di Desa Temukus dikarenkan lahan pertanian di Banjar Bingin Banjah kini sudah berkurang sehingga pemerintah Desa setempat mulai membatasi pembangunan khususnya pembangunan akomodasi pariwisata di Banjar Bingin Banjah.

Selain adanya trasnformasi fisik berupa akomodasi pariwisata terdapat pula transformasi infrastruktur, namun yang mengalami transformasi hanya panjang jalan walaupun dapat dikatakan transformasi panjang jalan ini masih rendah, Banjar yang mengalami transformasi infrastruktur panjang 
jalan, yakni Banjar Labuhan Aji. Hal ini dikarenkan adanya akomodasi pariwsata di Banjar Labuhan Aji memerlukan infrastrukur jalan yang memadai untuk para wisatawan dapat mengunjungi akomodasi pariwisata tersebut.

Berdasarkan pemabahasan tersebut transformasi akomodasi dan infrastruktur pariwisata di Desa Temukus mulai mengalami peningkatan, namun lain halnya dengan hasil penelitian Sumarabawa (2013) dengan penelitian yang berjudul "Ketersediaan Aksesibilitas Serta Sarana Dan Prasarana Pendukung Bagi Wisatawan Di Daerah Wisata Pantai Pasir Putih, Desa Prasi, Kecamatan Karangasem", mengatakan bahwa ketersediaan dan pemanfaatan akomodasi pariwisata pantai pasir putih Desa Prasi masih kurang, untuk ketersedian penginapan hanya terdapat 3 bangunan. Penginapan ini juga jarang digunakan sebagai tempat persinggahan bagi wisatawan karena wisatawan lebih memilih untuk bermalam di luar objek wisata pantai pasir putih sehingga penginapan ini kurang terawat, namun untuk akomodasi restaurant Desa Prasi telah memiliki beberapa restaurant yang mampu menunjang kenyamanan wisatawan, terdapat 12 warung dan 2 cafe dimana semua warung dan cafe telah ditata rapi disepanjang pinggiran pantai sehingga tidak mengganggu kenyamanan dan kegiatan wisatawan.

Ketersedian infrastruktur atau aksesibilitas seperti kondisi jalan menuju objek wisata pantai pasir putih masih sangat kurang bagus dan tidak memadai, terdapat beberapa jalan yang berlubang dibeberapa titik serta kondisi jalan yang belum teraspal dan masih menggunakan jalan tanah, semetara untuk lebar jalan hanya bekisar \pm 3 $m$ sehingga akan menyulitkan para wisatawan khususnya yang menggunakan roda empat, selain itu hanya terdapat satu jalur utama untuk menuju pantai pantai pasir putih dan tidak ada jalur alternatif lainnya.

\section{Transformasi Sosial Ekonomi Berbasis Pariwisata Di Desa Temukus}

Berkembangnya pariwisata di Desa Temukus tentunya memberikan kontribusi yang baik bagi masyarakat sekitar khusunya pada sektor penyerapan tenaga kerja, dimana dari adanya perkembangan pariwsata mengakibatkan terjadinya transformasi sosial ekonomi di Desa Temukus. Adapun Banjar yang mengalamai transformasi mata pencaharian tertinggi, yakni Banjar Labuhan $\mathrm{Aji}$ yang tingkat transformasi mata pencaharian sebgaai pelaku usaha wisata juga lebih tinggi dibandingkan transformasi mata pencaharaian sebagai petani maupun sebagai pemilik lahan sawah. Hal ini dikarenkan masyarakat Banjar Labuhan Aji memiliki kualitas yang cukup baik dalam industri pariwisata seperti memiliki kemampuan atau skill dalam berbahasa asing minimal menguasai bahas inggris, sehingga para pengelola objek wisata sebagaian besar menerima tenaga kerja dari masyarakat Banjar Bingin Banjah, selain itu tingginya masyarakat Banjar Labuhan Aji yang merubah mata pencaharian menjadi pelaku usaha wisata, dikarenakan sebagian besar masyarakatnya mempunyai keinginan untuk merubah nasib, ingin mencari pekerjaan yang lebih baik khususnya di bidang pariwisata, serta ingin mencari pengalaman khususnya di bidang pariwisata.

Terdapat pula banjar yang mengalami transformasi mata pencahraian terkecil, yakni Banjar Bingin Banjah yang mana hanya sedikit masyarakatnya bermatapencaharian sebagai pelaku usaha wisata dan jumlah masyarakat yang bermatapencahraian sebagai petani serta pemilik lahan tidak menglamai transformasi (tetap), hal ini dikarenakan tidak adanya keinginan masyarakatnya untuk merubah nasib, serta sebagian besar masyarakatnya berkeinginan untuk mengajegkan atau melestarikan lahan pertaniannya serta bermatapencaharia sebagai petani yang telah turun-temurun diwariskan oleh para generasi terdahulu.

Transformasi mata pencaharian dari adanya perkembangan pariwisata di Desa Temukus tentunya juga akan memberikan kontribusi terhadap transformasi pendapatan masyarakat Desa Temukus, dimana transformasi pendapatan tertinggi, yakni Banjar Labuhan Aji dengan tingkat persentase pendapatan pelaku usaha wisata lebih tinggi dibandingkan dengan Banjar lainnya, tentunya hal ini dikarenakan pendapatan pelaku usaha wisata di Banjar Labuhan Aji lebih tinggi dibandingakan dengan pendapatan pelaku usaha wisata di 
Banjar lainnya, sehingga hal ini membuat banyaknya masyarakat Labuhan Aji yang merubah mata pencahariannya menjadi pelaku usaha wisata.

Selain terdapat transformasi pendaptan tertinggi terdapat pula transformasi pendapatan terendah, yakni pada Banjar Bingin Banjah, hal ini dikarenakan sedikitnya masyarakat yang bermata pencaharian sebagai pelaku usaha wisata, sehingga pendapatan sebagai pelaku usaha wisata pun sedikit, serta pendapatan pada mata pencaharaian lainnya seperti petani dan pemilik lahan lainnya tidak mengalami transformasi atau tetap.

Hasil penelitian transformasi sosial ekonomi berbasis pariwisata berupa mata pencaharian dan pendapatan di Desa Temukus ini sejalan dengan hasil penelitian lainnya namun tetap dengan kajian yang sama salah satunya penelitian dari Rahmawati (2013) dengan judul penelitian "Konversi Lahan Pertanian Pesisir Desa Kelating, Kecamatan Kerambitan, Kabupaten Tabanan" mengemukakan bahwa adanya transformasi mata pencaharian masyarakat Desa Kelating, sekitar $48,3 \%$ yang semula bermata pencaharian sebagai petani berlaih menjadi wiraswasta yang berkecimpung dalam bidang pariwisata dan juga sebagai pedagang, hal ini dikarenakan adanya perkembangan pariwisata pesisir yang menyebabkan mulai meningkatnya harga jual lahan pertanian, sehingga beberapa petani di desa tersebut tergiur untuk menjual lahan pertaniannya, selain itu adanya peubahan pola pikir para petani yang ingin merubah nasib serta serta mencari pengalaman baru dalam bidang pariwsata juga memicu adanya perubahan mata pencaharaian dari petani menjadi wiraswasta maupun pedagang.

Transformasi mata pencaharian yang awalnya sebagai petani berubah menjadi wiswasta dan pedagang tentunya akan memberikan kontribusi terhadap pendapatan di masing-masing mata pencaharian, dimana pendapatan sebagai petani hanya berkisar Rp. 500.000 - Rp. 1000.000/bulan, namun untuk pendapatan sebagai wiraswasta yang berkecimpung dalam bidang pariwisata berkisar Rp. 1000.000 - Rp. 2000.000/bulan dan ada juga yang <Rp. 2000.000/bulan, serta pendapatan untuk pedagang berkisar Rp. 1000.000 - Rp. 2000.000/bulan.

\section{Simpulan Dan Saran}

Pariwisata mempunyai peranan penting dalam transformasi sosio-spasial berbasis pariwisata di Desa Temukus, dimana terjadi transformasi fisik berupa akomodasi pariwisata seperti restaurant, penginapan (hotel, villa, home stay), dan mini market (alfamart, minimart, toko, pedagang kecil) di Desa Temukus tahun 2012 dan 2016, yakni sebesar $105 \%$ termasuk transformasi tinggi. Serta transformasi infrastruktur berupa panjang jalan sebesar $204 \%$ termasuk transformasi tinggi. Serta terjadi transformasi sosial ekonomi berupa mata pencaharaian serta pendapatan di Desa Temukus, adapun transformasi mata pencaharian baik dari pelaku usaha wisata, petani, dan pemilik lahan sawah di Desa Temukus tahun 2012 adalah sebesar $85.21 \%$ termasuk transformasi tinggi. Serta terjadi transformasi pendapatan tahun 2012 dan 2016 sebesar $22.24 \%$ termasuk transformasi rendah.

Saran yang dapat disampaikan oleh peneliti, yaitu. (1) Bagi masyarakat sebaiknya meningkatkan pengetahuan tentang beberapa hal yang berkaitan perkembangan pariwisata Desa. Agar masyarakat Desa dapat mempersiapkan diri serta kemampuan demi mengikuti perubahan jaman khususnya pada perkembangan pariwisata Desa serta dapat berpartisipasi secara langsung dalam perkembangan pariwisata Desa tersebut. (2) Bagi pemerintah seharusnya lebih mampu menata ruang terbuka hijau yang ada, agar tidak terjadi alih fungsi lahan di beberapa daerah dan menyebabkan kepadatan serta ketimpangan antar banjar yang kemudian dapat mengakibatkan ketumpang tindihan perkembangan antar banjar di Desa Temukus. (3) Bagi penelitian sejenis hasil dari penelitian ini diharapkan dapat dijadikan refrensi atau acuan bagi peneliti lain yang berminat melakukan penelitian sejenis, dapat digunakan sebagai pertimbangan atau perbandingan dengan memperhatikan kendala-kendala yang dialami.

\section{Daftar Pustaka}

Atmaja, Dewa Made. 2015. "Dampak Strategi Petani Dalam Merubah Arah Pemanfaatan Lahan Sawah Terhadap Kenyataan Hidup Di Kota Denpasar". Media Komunikasi Geografi, Volume 16, Nomor 1 (hlm. 1-13). 
Fitri, Rahmafitria. 2014. "Eco-Resort dan Green Hotel di Indonesia : Model Sarana Akomodasi yang

Berkelanjutan". Jurnal Manajemen Resort \& Leisure, Volume 11, Nomor 2 (hlm. 1--22).

Happy Marpung, dan Bahar Herman. 2002. Pengantar Pariwisata. Bandung: Alfabeta.

Hanny, Aryunda. 2011. "Dampak Ekonomi Pengembangan Kawasan Ekowisata Kepulauan Seribu". Jurnal Perencanaan Wilayah dan Kota, Volume 22, Nomor. 1 (hlm. 1-16)

Kusudianto, Hadinoto. 1996. Perencanaan Pengembangan Destinasi Pariwisata. Jakarta: Universitas Indonesia.

Menuh, Ni Nyoman. 2016. "Karakteristik Wisatawan Backpacker Dan Dampaknya Terhadap Pariwisata Kuta, Bali". JUMPA, Volume 2, Nomor 2 (hlm. 1-12).

Rahmawati, Sutarjo, Treman. 2013. "Konversi Lahan Pertanian Pesisir Desa Kelating, Kecamatan Kerambitan, Kabupaten Tabanan". Jurnal Pendidikan Geografi,
Universitas Pendidikan Ganesha, Vol 3, Nomor 1 (hlm.1--10).

Rossi, Evita. 2012. "Dampak Perkembangan Pembangunan Sarana Akomodasi Wisata Terhadap Pariwisata Berkelanjutan Di Bali". Jurnal IImiah Pariwisata, Volume 3, Nomor 2, (hlm. 1-12).

Riani, Nurjanah. 2012 . "Studi Persepsi Dampak Perubahan Pemanfaatan Lahan Terhadap Kunjungan Wisata Di Pulau Pramuka Kepulauan Seribu". Jurnal Perencanaan Wilayah dan Kota, Volume 23, Nomor 2 (hlm. 118).

Sumarabawa, Astra Wesnawa, Made Astawa. 2013. "Ketersediaan Aksesibilitas Serta Sarana Dan Prasarana Pendukung Bagi Wisatawan Di Daerah Wisata Pantai Pasir Putih, Desa Prasi, Kecamatan Karangasem". Jurnal Pendidikan Geografi, Universitas Pendidikan Ganesha, Vol 2, Nomor 1 (hlm. 114).

Yoeti, Oka. A. 1999. Industri Kepariwisataan Dan Peluang Kesempatan Kerja. Jakarta: P.T. Pertja. 
